\title{
Optimizing compliance with surgical antimicrobial prophylaxis guidelines in patients undergoing gastrointestinal surgery at a referral teaching hospital in southern Iran: clinical and economic impact [Corrigendum]
}

Mahmoudi L, Ghouchani M, Mahi-Birjand M, Bananzadeh A, Akbari A. Infect Drug Resist. 2019;12:2437-2444.

The author has advised that they made a typing error in Table 1 on page 2441 and they did not notice this before the paper was published.
Infection and Drug Resistance

\section{Publish your work in this journal}

Infection and Drug Resistance is an international, peer-reviewed openaccess journal that focuses on the optimal treatment of infection (bacterial, fungal and viral) and the development and institution of preventive strategies to minimize the development and spread of resistance. The journal is specifically concerned with the epidemiology of
The value "121 (92.14\%)" in the row 'Timing $>48 \mathrm{hrs"}$ and column 'Group $1 * n(\%)$ ' should instead read "410 $(92.13 \%)$ ". 